\begin{abstract}
Ocena zakresu ruchu stawu kolanowego (ROM) oraz poziomu dolegliwości bólowych (VAA) u pacjentów po artroskopowej rekonstrukcji więzadła krzyżowego

A - opracowanie koncepcji i założeń (preparing concepts)

B - opracowanie metod (formulating methods)

$\mathrm{C}$ - przeprowadzenie badań (conducting research)

D - opracowanie wyników (processing results)

E - interpretacja i wnioski (interpretation and conclusions)

$\mathrm{F}$ - redakcja ostatecznej wersji (editing the final version)

\section{Assessment of knee joint range of motion and the level of pain in patients after arthroscopic ACL reconstruction in the selected physiotherapy model}

Sebastian Zduński ${ }^{1,3 A-F}$, Witold Rongies ${ }^{2 A, E}$, Marcin Ziółkowski ${ }^{3 E}$, Tomasz Kozieł ${ }^{1}$, Piotr Kazimierski ${ }^{3}$, Rafał Hałaj ${ }^{3}$, Janusz Sierdziński ${ }^{4}$

${ }^{1}$ Profemed Sport i Rehabilitacja, Grupa Luxmed, Warszawa, Profemed Sport and Rehabilitation, Luxmed Group, Warsaw

${ }^{2}$ Zakład Rehabilitacji Oddział Fizjoterapii II Wydziału Lekarskiego Warszawskiego Uniwersytetu Medycznego, Department of Rehabilitation, Physiotherapy Division of the Second Faculty of Medicine, Medical University of Warsaw

${ }^{3}$ MediQ Ortopedia i Rehabilitacja Sportowa, Warszawa, MediQ Sports Orthopaedics and Rehabilitation, Warsaw

${ }^{4}$ Zakład Informatyki Medycznej i Telemedycyny Warszawskiego Uniwersytetu Medycznego, Department of Medical Informatics and Telemedicine, Medical University of Warsaw

\section{Streszczenie}

Wstęp: Uszkodzenia ACL w większości przypadków wymagają specjalistycznego leczenia operacyjnego i fizjoterapeutycznego. Ważnym wyznacznikiem powodzenia działań fizjoterapeutycznych jest odzyskanie pełnego zakresu ruchu zgięcia i wyprostu stawu kolanowego oraz ograniczenie lub wyeliminowanie dolegliwości bólowych.

Materiat $i$ metody: Do badania włączono w sposób losowy 72 osoby z rozpoznanym całkowitym zerwaniem ACL, zakwalifikowanych do jego operacyjnego odtworzenia.

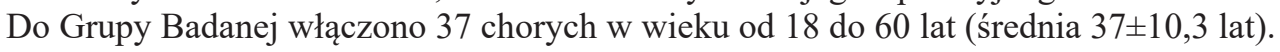
Wszyscy badani z tej grupy poddani zostali modelowi fizjoterapii, opartemu o uznane schematy leczenia usprawniającego, przez 4 tygodnie poprzedzające zabieg rekonstrukcyjny. Do Grupy Kontrolnej włączono 35 chorych w wieku od 18 do 60 lat (średnia 34 \pm 10,0 lat), którzy nie realizowali programu fizjoterapii przedoperacyjnej.

Wyniki: Zarówno w grupie Badanej, jak i Kontrolnej w kolejnych punktach pomiarowych zaobserwowano istotną statystycznie poprawę zakresu ruchu zgięcia i wyprostu $(\mathrm{p}<0,05)$. Analiza statystyczna wykazała znamiennie lepszy wyprost w Grupie Badanej w pierwszym i po 6 tygodniach od rekonstrukcji WKP $(\mathrm{p}<0,05)$. Zaobserwowano istotne statystycznie różnice w poziomie bólu u pacjentów z Grupy Badanej i Kontrolnej w kolejnych punktach pomiarowych $(\mathrm{p}<0,05)$. Zaobserwowano istotną statystycznie różnicę w ocenie poziomu bólu po 12. tygodniu od operacji dla Grupy Badanej $(p<0,05)$.
\end{abstract}




\section{Słowa kluczowe:}

\section{Key words: knee joint, anterior cruciate ligament, ROM, VAS}

\section{Abstract} physiotherapy programme.
Wnioski: Obserwowany szybszy powrót zakresu ruchu wyprostnego w operowanym stawie kolanowym, mniejsze natężenie bólu w końcowym, odległym punkcie pomiarowym w Grupie Badanej, mogą wskazywać na pewną wartość terapeutyczną przedoperacyjnej fizjoterapii.

\section{staw kolanowy, więzadło krzyżowe przednie, ROM, VAS}

Introduction: In the majority of cases, anterior cruciate ligament (ACL) injuries require specialist surgical and physiotherapeutic treatment. The fact that the patient regains a full range of flexion and extension in the knee joint as well as the reduction or elimination of pain is a significant determinant of successful physiotherapy.

Material and methods: The study included 72 randomly selected individuals with a complete ACL tear who were qualified for its surgical reconstruction. The research group included 37 patients aged 18-60 (mean age $37 \pm 10.3$ years). All the participants from this group underwent physiotherapy based on recognised schemes of rehabilitation and performed for 4 weeks before the reconstruction surgery. The control group included 35 patients aged $18-60$ (mean age $34 \pm 10.0$ years) who did not undergo any presurgical

Results: Both in the research group and in the control group, subsequent measurements revealed a statistically significant improvement in the range of flexion and extension $(\mathrm{p}<0.05)$. Statistical analysis revealed a significantly better extension 1 week and 6 weeks after the ACL reconstruction $(p<0.05)$ in the research group. Statistically significant differences in the level of pain in patients from both groups were noted in subsequent measurements $(\mathrm{p}<0.05)$. Also, a statistically significant difference concerning pain assessment 12 weeks after the reconstruction was noted in the research group $(\mathrm{p}<0.05)$.

Conclusions: A quicker recovery of the range of extension in the operated knee joint and lower intensity of pain in the final measurement noted in the research group may indicate a certain therapeutic value of presurgical physiotherapy.

\section{Wstęp}

Staw kolanowy jest największym i najbardziej złożonym stawem ludzkiego organizmu. Od jego prawidłowego funkcjonowania zależy, w dużym stopniu, możliwość przemieszczania się i pokonywania różnych przeszkód związanych z codzienną egzystencją. Również możliwość posługiwania się prawidłowym, a więc ekonomicznym i bezpiecznym stereotypem chodu decydującym o sprawności ogólnej człowieka, uwarunkowana jest stanem funkcjonalnym stawu kolanowego [1-5]. Dlatego też następstwa jego uszkodzeń w wyniku różnego rodzaju urazów, wraz z chorobą zwyrodnieniową (gonartrozą), należą do najczęstszych przyczyn zaburzeń w układzie szkieletowo-mięśniowym w obrębie kończyn dolnych. Do najbardziej spektakularnych następstw urazów stawu kolanowego zalicza się uszkodzenia w obrębie aparatu więzadłowego, zwłaszcza więzadła krzyżowego przedniego

\section{Introduction}

The knee joint is the biggest and most complex joint in a human body. An ability to move and overcome obstacles connected with everyday functioning depends to a large extent on its proper functioning. Also, an ability to use a proper, i.e. economic and safe stereotype of gait which determines general human fitness is related to the functional state of the knee joint [1-5]. Therefore, the effects of its damage resulting from various injuries, including gonarthrosis, belong to the most common disorders in the musculoskeletal system regarding lower limbs. The most profound effects of knee joint injuries include ligament, especially anterior cruciate ligament (ACL) injuries. In the vast majority of cases, a complete ACL tear requires specialist surgical treatment (ACL reconstruction) [6-17].

Most studies published to date regarding a complex treatment of patients with a complete ACL 
(ACL). Całkowite zerwanie ACL w zdecydowanej większości przypadków wymaga specjalistycznego leczenia operacyjnego (rekonstrukcji ACL) [6-17].

W większości dotychczas opublikowanych prac, dotyczących kompleksowego leczenia chorych po całkowitym zerwaniu ACL, przedstawiane są oceny działań terapeutycznych od momentu wykonania zabiegu rekonstrukcji ACL, niewiele jest jednak obserwacji wykazujących rolę przygotowania rehabilitacyjnego tych chorych do operacji odtworzenia ACL, choć w opinii wielu ortopedów i fizjoterapeutów w okresie tym można wykonać szereg korzystnych procedur fizykalno-kinezyterapeutycznych.

Badania oceniające rolę rehabilitacji przedoperacyjnej chorych $\mathrm{z}$ dysfunkcjami stawu kolanowego (w tym z całkowitym uszkodzeniem ACL), które przeprowadzili Shaarani [38], Swank [39] i Eitzen [40] oraz dotychczasowe doświadczenia autora pracy [22] wskazują na konieczność poszukiwania dowodów na potwierdzenie tezy, iż fizjoterapia w tym okresie jest równie ważna, jak po operacji.

Po wykonanej operacji bardzo ważnym etapem kompleksowej terapii, decydującym o optymalnym wyniku rekonstrukcji ACL, jest rehabilitacja [18-24]. Głównym celem leczenia usprawniającego jest przywrócenie pełnej funkcji stawu kolanowego i całej kończyny dolnej objętej leczeniem operacyjnym. Osiągnięcie tego celu stanowi podstawę do realizacji następnych, a więc powrotu chorego do pełnienia wszystkich ról społecznych i zawodowych oraz aktywności rekreacyjnych lub sportowych sprzed całkowitego zerwania ACL. Zadaniem kompleksowej rehabilitacji jest również zapobieganie wtórnym urazom i przeciążeniom innych części ciała, które kompensują niewydolność kolana w łańcuchu kinematycznym podczas różnorodnej aktywności $[24,25]$. Celem pracy jest ocena zakresu ruchu stawu kolanowego oraz poziomu dolegliwości bólowych u pacjentów po artroskopowej jednopęczkowej rekonstrukcji więzadła krzyżowego przedniego w wybranym modelu usprawniania leczniczego.

\section{Materiał i metody}

Do badań włączono w sposób losowy 72 osób (randomizacja I stopnia) z rozpoznanym zerwaniem ACL, zakwalifikowanych do jego operacyjnego odtworzenia. Rozpoznanie i kwalifikacja były oparte o pełne badanie kliniczne przeprowadzone przez tear present an assessment of therapeutic regimes implemented after the ACL reconstruction. However, there is a scarcity of findings regarding the role of rehabilitation that would prepare patients to the ACL reconstruction although, according to numerous orthopaedists and physiotherapists, several beneficial procedures from the field of physical therapy and kinesitherapy can be performed in this period.

The studies assessing the role of prehabilitation of patients with knee joint dysfunctions (including a complete ACL tear) carried out by Shaarani [38], Swank [39] and Eitzen [40] as well as our previous experiences [22] indicate the necessity to search for evidence to the thesis that physiotherapy in this period is as significant as physiotherapy after the surgery.

Rehabilitation after the surgery is a very important stage of a complex therapy which determines an optimal result of ACL reconstruction [18-24]. The main aim of rehabilitation is to recover a full function of the knee joint and the whole lower limb which was operated on. Achieving this aim constitutes the basis for realising further objectives, i.e. the return of patients to all their social and professional roles and to recreational and sports activity from before the complete ACL tear. Another aim of complex rehabilitation is to prevent secondary injuries and overloads in other parts of the body which compensate for a knee malfunction in a kinematic chain during various forms of activity [24,25]. The aim of the study is to assess the range of motion $(\mathrm{ROM})$ in the knee joint and the level of pain in patients after single-bundle arthroscopic ACL reconstruction in the selected model of rehabilitation.

\section{Material and methods}

The study included 72 randomly selected $\left(1^{\text {st }}\right.$ degree randomisation) individuals with a complete ACL tear who were qualified for its surgical reconstruction. The diagnosis and qualification were based on a full clinical examination carried out by a doctor specialising in orthopaedics and traumatology. The final diagnosis of a complete ACL tear and of the absence of another disease in the knee joint was made on the basis of magnetic resonance examination. The group included 31 women $(43.06 \%)$ and 41 men $(56.94 \%)$ whose mean age was 35 $(\mathrm{SD} \pm 10.1)$ and median age was 38.5 (minimum 18 years, maximum 60 years). All the patients who 
specjalistę ortopedii i traumatologii narządu ruchu. Badaniem rozstrzygającym o ostatecznym rozpoznaniu całkowitego zerwania ACL oraz o braku istnienia innego procesu chorobowego w stawie kolanowym było badanie rezonansu magnetycznego. W grupie tej było 31 kobiet $(43,06 \%)$ i 41 mężczyzn $(56,94 \%)$ o średniej wieku 35 lat $\mathrm{SD} \pm 10,1$ oraz medianie wieku 38,5 lat (minimum 18 lat, maksimum 60 lat). Wszyscy chorzy, wstępnie zakwalifikowani do badania otrzymali od lekarza udzielającego porady, propozycję fizjoterapii przedoperacyjnej. W wyniku dobrowolnej deklaracji badanych, dokonano randomizacji II stopnia i podziału tych osób na dwie grupy. Do pierwszej włączono chorych realizujących program usprawniania przedoperacyjnego, a do drugiej zakwalifikowano chorych, którzy nie realizowali programu fizjoterapii przedoperacyjnej. Program fizjoterapii pooperacyjnej był jednakowy $\mathrm{u}$ wszystkich badanych. Wszyscy uczestniczaccy w badaniu pacjenci poddali się pierwotnemu zabiegowi jednopęczkowej artroskopowej rekonstrukcji więzadła krzyżowego przedniego z użyciem ścięgna mięśnia półścięgnistego i smukłego. Kryteria włączenia do badania: wiek $>18$ r. ż. i $<60$ r. ż.; świadoma zgoda chorego na uczestnictwo w badaniu; deklaracja uczestniczenia w programie fizjoterapii przedoperacyjnej dla grupy badanej i brak takiej deklaracji dla grupy kontrolnej. Kryteria wyłączenia z badania wiek $<18$ r. ż. i $>60$ r. ż.; uznane przeciwwskazania do stosowania zabiegów fizykoterapeutycznych (dla grupy badanej); inne, istotne dysfunkcje w obrębie układu ruchu; brak świadomej zgody na uczestnictwo w badaniu; ogólny zły stan pacjenta.

Do Grupy Badanej włączono 37 chorych w wieku

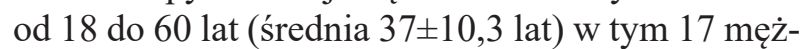
czyzn i 20 kobiet. Średnia wartość BMI dla osób $\mathrm{z}$ tej grupy wyniosła 24 . W badanej grupie 17 chorych miało rozpoznane uszkodzenie ACL w stawie kolanowym prawym, a 20 - w lewym. Ważnym etapem postępowania u pacjentów $\mathrm{z}$ tej grupy było wdrożenie rehabilitacji przedoperacyjnej, która miała na celu przygotowanie stawu kolanowego oraz samego pacjenta na funkcjonowanie w nowych warunkach. Wszyscy badani z tej grupy poddani zostali modelowi fizjoterapii opartemu o uznane schematy leczenia usprawniającego przez 28-30 dni poprzedzających zabieg rekonstrukcyjny, 2-3 razy w tygodniu. W sumie przeprowadzono od 10 do 12 sesji terapeutycznych trwających średnio ok. 120 minut każda. W czasie fizjoterapii przedoperacyjnej were initially qualified for the study were offered presurgical physiotherapy. After voluntary declarations, the patients were randomly divided into two groups ( $2^{\text {nd }}$ degree randomisation). The first group included patients who underwent prehabilitation, the second group included patients who did not undergo presurgical physiotherapy. The programme of postsurgical physiotherapy was the same for both groups. All the study participants underwent a single-bundle ACL reconstruction with the use of semitendinosus and gracilis tendon. The study inclusion criteria were as follows: age $>18$ years and $<60$ years, informed consent of the patient to participate in the study, declaration of participation in the presurgical physiotherapy programme for the research group and the lack of such declaration for the control group. The study exclusion criteria were as follows: age $<18$ years and $>60$ years, diagnosed counterindications to physiotherapy procedures (for the research group), other significant dysfunctions of the musculoskeletal system, the lack of informed consent of the patient to participate in the study, bad general state of the patient.

The research group included 37 patients aged $18-60$ (mean age $37 \pm 10.3$ years), i.e. 17 men and 20 women. Mean BMI value for these patients was 24. In this group, 17 patients were diagnosed with ACL injury in the right knee, while 20 patients had an injury in the left knee. Implementing prehabilitation in patients from this group was a significant element of the whole rehabilitation procedure, as it aimed at preparing the knee joint and the patient to function in new conditions. All the participants from this group underwent physiotherapy based on recognised rehabilitation schemes that lasted 28-30 days (2-3 times per week) before the reconstruction. In total, 10-12 therapeutic sessions lasting approximately 120 minutes each were carried out. During prehabilitation patients were informed about the procedures of pre- and postsurgical rehabilitation. Also, mutual expectations were discussed and patients were informed that knee rehabilitation means not only the strengthening of lower limb muscles but also working on the function of the whole lower limb as well as performing stabilising exercises and kinematic chain exercises. Presurgical therapy included the reduction of pain, oedema and inflammation, maintaining or improving ROM, mobilisation of the femoropatellar joint, isometric exercises of the quadriceps muscle, maintaining or improving gait patterns and learning to do exercises which 
poinformowano pacjentów o przebiegu rehabilitacji przed- i pooperacyjnej. Omówiono także wzajemne oczekiwania, uświadomiono pacjentom, iż rehabilitacja kolana to nie tylko wzmacnianie mięśni kończyny dolnej, ale także praca nad funkcją całej kończyny, ćwiczenia stabilizacji i ćwiczenia w łańcuchach kinematycznych. Terapia przedoperacyjna obejmowała zmniejszenie bólu, obrzęku i stanu zapalnego, utrzymanie lub poprawę ROM (ang. range of motion), mobilizację stawu rzepkowo-udowego, ćwiczenia izometryczne mięśnia czworogłowego uda, utrzymanie lub poprawę wzorca chodu, a także wytrenowanie ćwiczeń, które będą wykonywane w pierwszych dniach po operacji: zginanie kolana z suwaniem pięty po podłożu; unoszenie wyprostowanej kończyny: ang. stright leg raise SLR; miniprzysiady; elewacja kończyny; uświadomienie jak istotne jest uzyskanie pełnego wyprostu w stawie kolanowym oraz praktyczna nauka chodzenia o kulach. Poza tym wykonywano zabiegi fizykalne na okolicę stawu kolanowego z uszkodzonym ACL krioterapię miejscową, elektrostymulację mięśnia czworogłowego uda oraz pole magnetyczne zgodnie $\mathrm{z}$ tabelą procedur leczniczych zdefiniowanych przez producenta. will be performed in the first days after the surgery (flexing the knee with the heel moving on the floor, straight leg raise (SLR), mini squats, limb lifting), making the patients aware of the significance of reaching a full extension in the knee joint and practice of walking with crutches. Moreover, such physical therapy regimes as localised cryotherapy, quadriceps electrostimulation and magnetic field according to the table of treatment procedures defined by the producer were performed in the area of the knee joint.

The control group included 35 patients aged 18-60 (mean age $34 \pm 10.0$ years), i.e. 24 men and 11 women who did not undergo prehabilitation for various reasons. Apart from general recommendations of an orthopaedist and physiotherapist regarding general prophylaxis of the injury, the participants were instructed about special exercises for patients with ACL injury. Mean BMI value in this group was 25 . In the control group, 13 patients were diagnosed with ACL injury in the right knee, while 22 patients had the left knee injury.

There were no statistically significant differences between the groups regarding age, gender, BMI and the injury side (tab. 1).

Tab. 1. Charakterystyka grupy włączonej do badań

Tab. 1. Characteristics of the examined group

\begin{tabular}{|c|c|c|c|c|}
\hline $\begin{array}{l}\text { Parametry } \\
\text { Parameters }\end{array}$ & $\begin{array}{c}\text { Kryteria kwestionariusza } \\
\text { Questionnaire criteria }\end{array}$ & $\begin{array}{c}\text { GRUPA BADANA } \\
\text { Research group } \\
\mathbf{N}=\mathbf{3 7}\end{array}$ & $\begin{array}{c}\text { GRUPA KONTROLNA } \\
\text { Control group } \\
\mathbf{N}=\mathbf{3 5}\end{array}$ & $p($ test $t)$ \\
\hline \multirow{2}{*}{$\begin{array}{l}\text { Wiek (lata) } \\
\text { Age (years) }\end{array}$} & $\begin{array}{l}\text { Średnia } \\
\text { Mean }\end{array}$ & 37 & 34 & \multirow[b]{2}{*}{0.149} \\
\hline & $\begin{array}{l}\text { Odchylenie standardowe } \\
\text { Standard deviation }\end{array}$ & 10.3 & 10.0 & \\
\hline \multirow{2}{*}{$\begin{array}{l}\text { Płeć } \\
\text { Gender }\end{array}$} & $\mathrm{K}(\mathrm{F})$ & 20 & 11 & \multirow[b]{2}{*}{0.054} \\
\hline & $\mathrm{M}(\mathrm{M})$ & 17 & 24 & \\
\hline \multirow{2}{*}{ BMI } & $\begin{array}{l}\text { Średnia } \\
\text { Mean }\end{array}$ & 24 & 25 & \multirow[b]{2}{*}{0.165} \\
\hline & $\begin{array}{l}\text { Odchylenie standardowe } \\
\text { Standard deviation }\end{array}$ & 3.4 & 3.1 & \\
\hline \multirow{2}{*}{$\begin{array}{l}\text { Staw kolanowy } \\
\text { Knee joint }\end{array}$} & $\begin{array}{l}\text { Lewy } \\
\text { Left }\end{array}$ & 20 & 22 & \multirow[b]{2}{*}{0.456} \\
\hline & $\begin{array}{l}\text { Prawy } \\
\text { Right }\end{array}$ & 17 & 13 & \\
\hline
\end{tabular}

Do Grupy Kontrolnej włączono 35 chorych w wieku od 18 do 60 lat (34 $\pm 10,0$ lat), w tym 24 mężczyzn i 11 kobiet, którzy z różnych powodów zrezygnowali z rehabilitacji przedoperacyjnej. Poza ogólnymi zaleceniami lekarza ortopedy i fizjoterapeuty w zakresie ogólnej profilaktyki schorzenia, badanym tej grupy udzielono instruktażu ćwiczeń
In order to assess the patients, ROM in the knee joint was measured. The examination started with a patient lying in a prone position and the foot of an examined limb positioned behind the edge of the surface on which the patient was lying. The thigh was stabilised. The stationary arm of a goniometer was positioned along the long thigh axis and towards 
specjalnych dla chorych $\mathrm{z}$ uszkodzonym ACL. Średnia wartość BMI dla osób z tej grupy wyniosła. W badanej grupie 13 chorych miało rozpoznane uszkodzenie ACL w stawie kolanowym prawym, a 22 - w lewym.

Pomiędzy badanymi grupami nie było statystycznie istotnej różnicy $\mathrm{w}$ zakresie wieku, płci, BMI oraz strony urazu (Tabela 1).

Do oceny badanych wykorzystano badanie zakresu ruchu stawu kolanowego. Pozycją wyjściową chorego było leżenie przodem, stopa kończyny badanej pozostawała poza podłożem. Stabilizowano udo. Ramię nieruchome kątomierza (goniometru) ustawione było wzdłuż osi długiej uda, wycelowane w krętarz większy kości udowej, a ramię ruchome wzdłuż goleni, skierowane na kostkę boczną. Oś przyrządu pomiarowego ustawiona była $\mathrm{w}$ okolicy głowy kości strzałkowej, zgodnie z osią poprzeczną stawu. Ruch czynnego zgięcia i wyprostu w stawie kolanowym odbywał się z asekuracją badającego fizjoterapeuty $[25,34,35]$. Do oceny dolegliwości operowanego stawu kolanowego użyto wizualno-analogowej skal bólu (ang. Visual Analogue Scale$V A S$ ) jest metodą służącą do oceny subiektywnej natężenia bólu. Określanie natężenia bólu za pomocą skali VAS polegało na zaznaczeniu przez badanego punktu na linii o długości $10 \mathrm{~cm}$, który w odczuciu subiektywnym badanego chorego odpowiadał odczuwanemu natężeniu bólu, gdzie wartości 0 przypisywano całkowity brak bólu, a 10 - najsilniejszy ból, jaki można sobie wyobrazić. Wyrażenie nasilenia bólu w wartościach numerycznych pozwoliło na porównywanie zarówno w badaniach kontrolnych u pojedynczego chorego, jak i porównaniach międzyosobniczych. Metoda ta ze względu na swoją prostotę oraz uniwersalne zastosowanie jest jednym z najpowszechniej stosowanych narzędzi pomiaru natężenia dolegliwości bólowych $[27,33]$.

Przy analizie materiału wykorzystano następujące analizy statystyczne. Do opisu zmiennych ilościowych użyte zostały standardowe statystyki opisowe: wartości średnie, odchylenia standardowe, mediany, kwartyle i zakresy. Przy analizie zmiennych o rozkładzie normalnym użyto testu t-studenta. Przy analizie zmiennych niemających rozkładu normalnego użyto testu U Manna-Whitney'a oraz testu Wilcoxona; Do analizy materiału wykorzystano także analizę wariancji ANOVA. Do oceny statystycznej użyto programu Excel oraz Statistica 10.0. $\mathrm{Za}$ poziom istotności przyjęto wartości $\mathrm{p}<0,05$. Obliczenia statystyczne wykonywane były w the greater trochanter, while the movable arm was positioned along the shin towards the lateral ankle. The centre of the measuring device was placed at the head of fibula in line with the transverse axis of the joint. A movement of active flexion and extension in the knee joint was performed under the supervision of the physiotherapist $[25,34,35]$. In order to assess pain in the operated knee joint, Visual Analogue Scale (VAS) was applied. It is a method aimed at subjective assessment of pain intensity. Pain intensity with the use of VAS was assessed by marking a point which reflected pain intensity subjectively defined by the patient on a 10-centimetre line, where 0 meant no pain and 10 reflected the strongest pain imaginable. Expressing pain intensity in numerical values made it possible to draw comparisons both between control examinations in one patient and between different patients. Due to its simplicity and universal application, this method is one of the most widely used tools for measuring pain intensity $[27,33]$.

The statistical analysis methods used in this study are described below. In order to describe numerical variables, standard descriptive statistics, i.e. mean values, standard deviations, medians, quartiles and ranges were applied. While analysing normal distribution variables, Student's t-test was used, while in the analysis of variables without normal distribution, Mann-Whitney U test and Wilcoxon test were applied. Moreover, the analysis of variance (ANOVA) was performed. Statistical calculations were made with Excel and Statistica 10.0 software. Statistical significance was set at the level of $p<0.05$. Statistical calculations were made in the Department of Medical Information Technology and Telemedicine of Warsaw Medical University. The study was accepted by the Bioethical Commission of Warsaw Medical University no. KB/35/2013. All the persons qualified for the study gave their informed consent to participate in the study.

\section{Results}

Knee joint ROM in both groups was examined three times, i.e. 1 week, 6 weeks and 12 weeks after the ACL reconstruction.

The ranges of flexion in an operated limb examined 1 week after the ACL reconstruction did not differ significantly between the two groups. Mean values defining the level of extension deficit in the 
Zakładzie Informatyki Medycznej i Telemedycyny Warszawskiego Uniwersytetu Medycznego. Badanie uzyskało zgodę Komisji Bioetycznej przy Warszawskim Uniwersytecie Medycznym KB/35/2013. Wszystkie osoby zakwalifikowane do eksperymentu wyraziły świadomą zgodę na udział w badaniu.

\section{Wyniki}

Badanie zakresów ruchu w stawach kolanowych w obu badanych grupach przeprowadzono w trzech terminach: w pierwszym tygodniu, po 6 tygodniach i po 12 tygodniach po rekonstrukcji ACL.

Zakresy ruchu zgięcia w kończynie operowanej, w pierwszym tygodniu po zabiegu rekonstrukcji ACL, nie różniły się w sposób istotny pomiędzy obserwowanymi grupami. Średnie wartości określające stopień deficytu wyprostu w stawie kolanowym, były większe w Grupie Kontrolnej. Przeprowadzona analiza statystyczna wykazała znamiennie mniejszy deficyt wyprostu w Grupie Badanej $(p<0,05)$. Nie stwierdzono istotnych odstępstw od fizjologicznych wartości zakresów ruchu czynnego w stawie kolanowym w obu grupach w kończynach nieoperowanych (Tabela 2).

W badaniu po 6 tygodniach od rekonstrukcji ACL zaobserwowano istotną poprawę wartości zakresów ruchu czynnego zgięcia i wyprostu w stawach kolanowych, zarówno w grupie Badanej, jak i Kontrolnej. Jednak w Grupie Badanej wyniki analizy statystycznej wskazują na korzystniejsze, bliższe wartościom fizjologicznym, zakresy czynnego wyprostu $\mathrm{w}$ stawach kolanowych kończyny operowanej $(p<0,05)$. Nie stwierdzono istotnych odstępstw od fizjologicznych wartości zakresów knee joint were higher in the control group. The statistical analysis revealed significantly lower extension deficit in the research group $(p<0.05)$. No significant deviations from physiological values of active ROM in the knee joint of a non-operated limb were noted in either of the groups (tab. 2).

In the examination performed 6 weeks after the ACL reconstruction, a significant improvement in the values of active ranges of flexion and extension in the knee joint was noted both in the research and in the control group. However, the results of the statistical analysis in the research group indicated better ranges of active extension in the knee joint of an operated limb which are closer to physiological values $(p<0.05)$. No significant deviations from physiological values of an active movement in the knee joint of a non-operated limb were noted in either of the groups (tab. 3).

The values of active ROM in the operated knee joints obtained in the examination performed 12 weeks after the reconstruction differed slightly from physiological values. In this examination, no statistically significant differences between the groups were noted regarding ROM in the operated knee joints (tab. 4).

In the first examination (after the first week) and in the second examination (after 6 weeks) performed after the ACL reconstruction, no significant differences between the groups regarding a subjective assessment of pain intensity (VAS) in the operated knee joints were noted $(p>0.05)$. In the examination carried out 12 weeks after the reconstruction, lower values of pain intensity in the area of the operated knee joint were noted in the research group. The observed difference in pain intensity between the groups was statistically significant $(\mathrm{p}<0.05)$ (tab. 5).

Tab. 2. Wyniki pomiarów zakresów ruchu czynnego w stawach kolanowych w badanych grupach Tab. 2. Results of the measurements of active ROM in the knee joint in the examined groups

\begin{tabular}{|c|c|c|c|c|c|c|c|}
\hline \multirow[b]{2}{*}{$\begin{array}{l}\text { Pomiary zakresu ruchu staw kolanowy (stopnie) } \\
\text { ROM measurements in the knee joint (degrees) }\end{array}$} & \multicolumn{3}{|c|}{$\begin{array}{l}\text { GRUPA BADANA } \\
\text { Research group }\end{array}$} & \multicolumn{3}{|c|}{$\begin{array}{l}\text { GRUPA KONTROLNA } \\
\text { Control group }\end{array}$} & \multirow[b]{2}{*}{$\begin{array}{c}\text { P (test U } \\
\text { Manna- } \\
\text {-Whitneya) }\end{array}$} \\
\hline & $\mathbf{N}$ & $\begin{array}{l}\text { Średnia } \\
\text { Mean }\end{array}$ & $\begin{array}{c}\text { Odchylenie } \\
\text { Standardowe } \\
\text { Standard } \\
\text { deviation }\end{array}$ & $\mathbf{N}$ & $\begin{array}{l}\text { Średnia } \\
\text { Mean }\end{array}$ & $\begin{array}{c}\text { Odchylenie } \\
\text { Standardowe } \\
\text { Standard } \\
\text { deviation }\end{array}$ & \\
\hline $\begin{array}{c}\text { Zgięcie nieoperowana } \\
\text { Flexion - non-operated limb }\end{array}$ & 37 & 139 & 5,8 & 35 & 137 & 5,9 & 0,457 \\
\hline $\begin{array}{l}\text { Zgięcie operowana } \\
\text { Flexion - operated limb }\end{array}$ & 37 & 68 & 19,4 & 35 & 71 & 21,2 & 0,597 \\
\hline $\begin{array}{l}\text { Wyprost nieoperowana } \\
\text { Extension - non-operated limb }\end{array}$ & 37 & 0 & 0,0 & 35 & 0 & 0,8 & 0,317 \\
\hline $\begin{array}{c}\text { Wyprost operowana } \\
\text { Extension - operated limb }\end{array}$ & 37 & 2 & 3,5 & 35 & 4 & 5,0 & 0,017 \\
\hline
\end{tabular}


Tab. 3. Wyniki pomiarów zakresów ruchu w stawach kolanowych w badanych grupach po 6 tygodniach Tab. 3. Results of the measurements of ROM in the knee joint performed after 6 weeks

\begin{tabular}{|c|c|c|c|c|c|c|c|}
\hline \multirow[b]{2}{*}{$\begin{array}{l}\text { Pomiary zakresu ruchu staw kolanowy (stopnie) } \\
\text { ROM measurements in the knee joint (degrees) }\end{array}$} & \multicolumn{3}{|c|}{$\begin{array}{l}\text { GRUPA BADANA } \\
\text { Research group }\end{array}$} & \multicolumn{3}{|c|}{$\begin{array}{l}\text { GRUPA KONTROLNA } \\
\text { Control group }\end{array}$} & \multirow[b]{2}{*}{$\begin{array}{c}\text { P (test U } \\
\text { Manna- } \\
\text {-Whitneya) }\end{array}$} \\
\hline & $\mathbf{N}$ & $\begin{array}{l}\text { Średnia } \\
\text { Mean }\end{array}$ & $\begin{array}{c}\text { Odchylenie } \\
\text { Standardowe } \\
\text { Standard } \\
\text { deviation }\end{array}$ & $\mathbf{N}$ & $\begin{array}{l}\text { Średnia } \\
\text { Mean }\end{array}$ & $\begin{array}{c}\text { Odchylenie } \\
\text { Standardowe } \\
\text { Standard } \\
\text { deviation }\end{array}$ & \\
\hline $\begin{array}{l}\text { Zgięcie nieoperowana } \\
\text { Flexion - non-operated limb }\end{array}$ & 37 & 140 & 5.3 & 35 & 139 & 5.0 & 0.495 \\
\hline $\begin{array}{l}\text { Zgięcie operowana } \\
\text { Flexion - operated limb }\end{array}$ & 37 & 120 & 10.4 & 35 & 116 & 14.1 & 0.217 \\
\hline $\begin{array}{l}\text { Wyprost nieoperowana } \\
\text { Extension - non-operated limb }\end{array}$ & 37 & 0 & 0.0 & 35 & 0 & 0.0 & 0.995 \\
\hline $\begin{array}{c}\text { Wyprost operowana } \\
\text { Extension - operated limb }\end{array}$ & 37 & 0 & 1.1 & 35 & 1 & 2.3 & 0.009 \\
\hline
\end{tabular}

Tab. 4. Wyniki pomiarów zakresów ruchu w stawach kolanowych w badanych grupach po 12 tygodniach Tab. 4. Results of the measurements of ROM in the knee joint performed after 12 weeks

\begin{tabular}{|c|c|c|c|c|c|c|c|}
\hline \multirow[b]{2}{*}{$\begin{array}{l}\text { Pomiary zakresu ruchu staw kolanowy (stopnie) } \\
\text { ROM measurements in the knee joint (degrees) }\end{array}$} & \multicolumn{3}{|c|}{$\begin{array}{l}\text { GRUPA BADANA } \\
\text { Research group }\end{array}$} & \multicolumn{3}{|c|}{$\begin{array}{l}\text { GRUPA KONTROLNA } \\
\text { Control group }\end{array}$} & \multirow[b]{2}{*}{$\begin{array}{c}\text { P (test U } \\
\text { Manna- } \\
\text {-Whitneya) }\end{array}$} \\
\hline & $\mathbf{N}$ & $\begin{array}{l}\text { Średnia } \\
\text { Mean }\end{array}$ & $\begin{array}{c}\text { Odchylenie } \\
\text { Standardowe } \\
\text { Standard } \\
\text { deviation }\end{array}$ & $\mathbf{N}$ & $\begin{array}{l}\text { Średnia } \\
\text { Mean }\end{array}$ & $\begin{array}{c}\text { Odchylenie } \\
\text { Standardowe } \\
\text { Standard } \\
\text { deviation }\end{array}$ & \\
\hline $\begin{array}{c}\text { Zgięcie nieoperowana } \\
\text { Flexion - non-operated limb }\end{array}$ & 37 & 136 & 21.9 & 35 & 138 & 5.5 & 0.528 \\
\hline $\begin{array}{l}\text { Zgięcie operowana } \\
\text { Flexion - operated limb }\end{array}$ & 37 & 133 & 7.7 & 35 & 131 & 8.5 & 0.388 \\
\hline $\begin{array}{l}\text { Wyprost nieoperowana } \\
\text { Extension - non-operated limb }\end{array}$ & 37 & 0 & 0.0 & 35 & 0 & 0.0 & 0.995 \\
\hline $\begin{array}{l}\text { Wyprost operowana } \\
\text { Extension - operated limb }\end{array}$ & 37 & 0 & 0.0 & 35 & 0 & 0.0 & 0.995 \\
\hline
\end{tabular}

Tab. 5. Wartości natężenia odczuwanego bólu w okolicy operowanego stawu kolanowego (VAS) w Grupie Badanej

i Kontrolnej w 1., 6. i 12. tygodniu po rekonstrukcji WKP

Tab. 5. Values of pain intensity in the area of the operated knee joint (VAS) in the research and control group 1 week, 6 weeks and 12 weeks after the ACL reconstruction

\begin{tabular}{|c|c|c|c|c|c|c|c|}
\hline \multirow[b]{2}{*}{$\begin{array}{l}\text { Natężenie bólu (skala VAS) } \\
\text { Pain intensity (VAS) }\end{array}$} & \multicolumn{3}{|c|}{$\begin{array}{l}\text { GRUPA BADANA } \\
\text { Research group }\end{array}$} & \multicolumn{3}{|c|}{$\begin{array}{l}\text { GRUPA KONTROLNA } \\
\text { Control group }\end{array}$} & \multirow[b]{2}{*}{$p$ (test t) } \\
\hline & $\mathbf{N}$ & $\begin{array}{l}\text { Średnia } \\
\text { Mean }\end{array}$ & $\begin{array}{c}\text { Odchylenie } \\
\text { Standardowe } \\
\text { Standard } \\
\text { deviation }\end{array}$ & $\mathbf{N}$ & $\begin{array}{l}\text { Średnia } \\
\text { Mean }\end{array}$ & $\begin{array}{c}\text { Odchylenie } \\
\text { Standardowe } \\
\text { Standard } \\
\text { deviation }\end{array}$ & \\
\hline $\begin{array}{c}1 \text { tydzień. po operacji } \\
1 \text { week after the reconstruction }\end{array}$ & 37 & 3.1 & 2.3 & 35 & 2.8 & 2.1 & 0.481 \\
\hline $\begin{array}{c}6 \text { tygodni po operacji } \\
6 \text { weeks after the reconstruction }\end{array}$ & 37 & 1.4 & 1.2 & 35 & 1.9 & 1.6 & 0.105 \\
\hline $\begin{array}{c}12 \text { tygodni po operacji } \\
12 \text { weeks after the reconstruction }\end{array}$ & 37 & 0.7 & 0.9 & 35 & 1.4 & 1.3 & 0.009 \\
\hline
\end{tabular}

ruchu czynnego w stawie kolanowym w obu grupach w kończynach nieoperowanych (Tabela 3).

Uzyskane wartości czynnych zakresów ruchu w operowanych stawach kolanowych, w badaniu przeprowadzonym po 12 tygodniach, nieznacznie różniły się od pożądanych wartości fizjologicznych. W tej

\section{Discussion}

In the work by Smith et al., which is a result of meta-analysis of the studies on the role of rehabilitation in patients with ACL injuries published in recent years, the authors agreed that rehabilitation 
obserwacji nie stwierdzono istotnych statystycznie różnic w ruchomości operowanych stawów kolanowych pomiędzy badanymi grupami (Tabela 4).

W badaniach - pierwszym (w 1. tygodniu) i drugim (po 6 tygodniach) - przeprowadzonych po zabiegu rekonstrukcji WKP nie zaobserwowano istotnych różnic w subiektywnej ocenie natężenia bólu (VAS) okolicy operowanego stawu kolanowego pomiędzy badanymi grupami $(\mathrm{p}>0,05)$. W badaniu po 12 tygodniach od zabiegu niższe średnie wartości natężenia bólu odczuwanego w okolicy operowanego stawu kolanowego stwierdzono w Grupie Badanej. Zaobserwowana różnica ocenianego natężenia bólu pomiędzy badanymi grupami była istotna statystycznie $(\mathrm{p}<0,05)$ (Tabela 5).

\section{Dyskusja}

W pracy Smith'a i wsp., która jest wynikiem przeprowadzonej meta analizy prac dotyczących roli rehabilitacji chorych $\mathrm{z}$ uszkodzonym ACL, opublikowanych $\mathrm{w}$ ostatnich kilku latach, autorzy zgodnie stwierdzają, iż rehabilitacja wywiera znaczący wpływ na końcowy wynik rekonstrukcji tego więzadła. W konkluzji badacze wskazują na konieczność poszukiwania kompleksowego, standardowego programu rehabilitacji przed i po operacji rekonstrukcji ACL, pozwalającego osiągnąć optymalnie dobre wyniki dla tej grupy chorych [28]. W badaniu własnym wybrane i uzyskane wyniki w okresie pooperacyjnym pozwalają na stwierdzenie, iż włączenie leczenia fizjoterapeutycznego przed zabiegiem rekonstrukcji ACL jest korzystnym działaniem w programie kompleksowego postępowania terapeutycznego [28]. Potwierdzają to również inni, choć nieliczni badacze tematu [38-40]. Jedną z prac, w której autorzy wykazali istotną wartość rehabilitacji przedoperacyjnej w leczeniu schorzeń i chorób stawu kolanowego, jest badanie Swanka i wsp. [39]. Badanie dotyczyło 71 osób zakwalifikowanych do rozległej artroskopii stawu kolanowego. Głównym celem obserwacji było wykazanie wpływu rehabilitacji przedoperacyjnej na poprawę siły i możliwości funkcjonalnych stawu kolanowego przed planową artroskopią, Rehabilitacja przedoperacyjna okazała się skutecznym sposobem przyrostu siły mięśniowej i poprawy w zakresie możliwości wykonywania zadań funkcjonalnych u osób przed zabiegiem artroskopii stawu kolanowego [39]. Inną, równie ciekawą publikacją dotyczącą exerts significant influence on the final effects of the ligament reconstruction. In their conclusions, the authors indicated the necessity to search for a complex, standard rehabilitation programme implemented before and after the ACL reconstruction which would allow for achieving optimally good outcomes for this group of patients [28]. The selected results obtained in a postsurgical period led to a conclusion that implementing physiotherapy prior to the ACL reconstruction is a beneficial procedure in a complex therapy programme [28]. It is also confirmed by several other authors [38-40]. The study by Swank et al. is one of the works in which the authors revealed a significant value of prehabilitation for the treatment of knee joint diseases [39]. The study included 71 individuals qualified for a total knee arthroplasty. The main aim of the observation was to reveal the effects of prehabilitation on an improvement in the strength and function of the knee joint before the arthroplasty. Prehabilitation proved to be an efficient way of regaining muscle strength and improving abilities of performing functional tasks in patients before knee arthroplasty [39]. Another interesting publication regarding the issue of assessing the value of prehabilitation in patients with knee joint dysfunction which has a similar research thesis to our work is the study by Shaarani et al. [38]. In this study, 20 volunteers awaiting ACL reconstruction were randomly divided into two groups. The first group was a control group, while the other group underwent a special 6-week programme of kinesitherapy carried out under the supervision of a physiotherapist in the out-patient conditions. Moreover, patients from this group were instructed on how to perform the exercises in home conditions. The assessment was performed twice, i.e. directly before the reconstruction and 12 weeks after the surgery. A comparative analysis made on the basis of a single-legged hop test and the results of modified Cincinnati scale revealed that a 6-week programme of presurgical exercises applied in the group of patients qualified for ACL reconstruction led to a significant improvement in the knee function compared to the group of patients who did not exercise $(p<0.05)$. These effects were retained until the $12^{\text {th }}$ week after the surgery [38].

Another significant work which confirmed the value of physiotherapy in the case of ACL injuries is the study by Eitzen et al. [40] carried out on 100 patients. In this group, all the participants experienced a complete ACL tear after a knee injury and 
tematyki oceny wartości rehabilitacji przedoperacyjnej u chorych $\mathrm{z}$ dysfunkcją stawu kolanowego jest, bardzo zbliżone pod względem hipotezy badawczej prezentowanej pracy, badanie Shaarani i wsp. [38], w którym 20 ochotników oczekujących na zabieg rekonstrukcji ACL poddano randomizacji na dwie grupy. Pierwsza stanowiła grupę kontrolną, druga - grupę, w której przed zabiegiem operacyjnym włączono przez 6 tygodni specjalny program kinezyterapii prowadzonych pod kontrolą fizjoterapeuty w warunkach ambulatoryjnych. Dodatkowo chorym z tej grupy udzielono instruktażu ćwiczeń do wykonywania w warunkach domowych. Oceny dokonano dwukrotnie: bezpośrednio przed zabiegiem i w 12. tygodniu po rekonstrukcji ACL. Analiza porównawcza wykazała, iż 6-tygodniowy program ćwiczeń przedoperacyjnych stosowany w grupie chorych zakwalifikowanych do rekonstrukcji ACL spowodował istotną poprawę funkcji stawu kolanowego na podstawie testu single-legged hop test i wyników zmodyfikowanej skali Cincinnati, w stosunku do grupy niećwiczącej $(\mathrm{p}<0,05)$. Efekty te utrzymywały się aż do 12 . tygodnia po zabiegu [38].

Kolejną ważną pracą potwierdzającą wartość działań fizjoterapeutycznych w przypadku uszkodzeń ACL, jest badanie Eitzena i wsp [40], które dotyczyło grupy 100 chorych. W grupie tej, w której wszyscy doznali w wyniku przebytego urazu stawu kolanowego całkowitego zerwania ACL, włączono 5-tygodniowy program rehabilitacji, wykorzystującej specjalny zestaw ćwiczeń leczniczych. Oceniano funkcję stawu kolanowego badanych pacjentów przed rozpoczęciem i po zakończeniu programu kinezyterapii. Zgodnie z wynikami tych badań 5-tygodniowy program rehabilitacji prowadził do znacznej poprawy funkcji stawu kolanowego. Prawidłowo prowadzona rehabilitacja znacząco może poprawić funkcję stawu kolanowego przed zaplanowaną rekonstrukcją ACL lub też być pierwszym krokiem do późniejszego postępowania nieoperacyjnego [40].

$\mathrm{W}$ badaniu własnym oceny pooperacyjnej wykonano w okresach, które odpowiadały charakterystycznym fazom rehabilitacji chorych po rekonstrukcji ACL: w pierwszym tygodniu, po 6 tygodniach oraz po 12 tygodniach od zabiegu operacyjnego.

Do oceny pooperacyjnej wykorzystano badanie zakresu ruchu. Badanie to jest często zalecane przez czołowych badaczy tego tematu, ponieważ brak fizjologicznych zakresów ruchu w stawie kolanowym underwent a 5-week rehabilitation programme in which a special set of exercises was applied. Knee joint function of the participants was assessed prior to and after the kinesitherapy programme. According to the results, the 5-week programme led to a considerable improvement in knee joint function. Proper rehabilitation may significantly improve knee joint function before the ACL reconstruction or may be the first step towards further nonsurgical procedures [40].

In the present study, postsurgical assessment was performed in the periods which referred to characteristic phases of rehabilitation after ACL reconstruction, i.e. 1 week, 6 weeks and 12 weeks after the surgery.

In the postsurgical assessment, ROM examination was employed. This test is often recommended by the leading researchers in this field since the lack of physiological ROM in the knee joint (especially the lack of physiological extension) constitutes a serious threat to the reconstructed ligament and the joint itself $[11,34,35]$.

According to Quelarda et al., disturbed ROM is the most common complication after the ACL reconstruction. The authors of this study formulated this conclusion on the basis of the results obtained in the observation of 217 patients after the ACL reconstruction. The primary aim of this observation was to determine presurgical factors responsible for a lengthened deficit of ROM after the ACL reconstruction. ROM in the knee joint was assessed with the use of a goniometer once before the ACL reconstruction as well as 6 and 12 weeks after the surgery. Moreover, seven risk factors which may affect final treatment outcomes, i.e. age, gender, presurgical ROM limitation, meniscus damage, bone damage, delayed surgery up to 45 days and rehabilitation, were taken into account. The results revealed that presurgical ROM limitation and typical damage of the lateral condyle of the femur and tibial plateau are the most significant factors hampering rehabilitation after the ACL reconstruction [34].

In another study, Isberg et al. concluded that early work on knee joint extension after ACL reconstruction did not affect excessive knee joint relaxation [35].

In their study, Shelbourne et al. revealed a correlation between loss of knee ROM and osteoarthritic changes observed in X-ray images in the long term after the ACL reconstruction. These results were related to decreased knee joint function subjectively assessed by patients. The authors of this research 
(zwłaszcza wyprostu), stanowi poważne zagrożenie dla przeszczepionego więzadła oraz samego stawu $[11,34,35]$.

Według Quelarda i wsp. zaburzony zakres ruchu pozostaje najczęstszą komplikacją po rekonstrukcji ACL. Autorzy tego badania sformułowali ten wniosek na podstawie osiągniętych wyników w obserwacji dotyczącej 217 pacjentów po rekonstrukcji ACL. Podstawowym celem tej obserwacji było określenie przedoperacyjnych czynników odpowiedzialnych za przedłużony deficyt zakresu ruchu po rekonstrukcji ACL. Oceny zakresów ruchu w stawie kolanowym wykonano za pomocą goniometru dzień przed zabiegiem rekonstrukcji ACL oraz po 6 i 12 tygodniach po operacji. Uwzględniono także siedem czynników ryzyka mogących wpłynąć na wynik końcowy leczenia: wiek, płeć, przedoperacyjne ograniczenie zakresu ruchu, uszkodzenia łąkotki, uszkodzenia kości, opóźnienie operacji $<45$ dni i rehabilitację. Wyniki badania wykazały, iż przedoperacyjne ograniczenie zakresu ruchu i typowe uszkodzenia bocznego kłykcia kości udowej i plateau piszczeli są najważniejszymi utrudniającymi czynnikami w pooperacyjnej rehabilitacji po rekonstrukcji ACL [34].

Isberg i wsp. w swojej pracy przekonują, iż wczesna praca nad wyprostem w stawie kolanowym po rekonstrukcji ACL nie wpływa negatywnie na nadmierne rozluźnienie stawu kolanowego [35].

Shelbourne i wsp. w swoim badaniu wykazali związek pomiędzy utratą ROM stawu kolanowego i zmianami zwyrodnieniowymi obserwowanymi na zdjęciach RTG, w dłuższej perspektywie po rekonstrukcji ACL. Wyniki te były skorelowane z niższą subiektywną oceną funkcji stawu kolanowego przez pacjentów. Autorzy tego badania zalecają wypracowanie pełnego i symetrycznego ROM poprzez realizację programu fizjoterapii przed rekonstrukcją WKP i po niej. Uważają jednocześnie, iż należy szczególną uwagę zwrócić na dokładne i precyzyjne zbadanie ROM, a także na osiągnięcie i utrzymanie pełnego, symetrycznego ROM w dłuższej perspektywie po rekonstrukcji ACL [36].

W przeprowadzonym badaniu własnym, oceniając zakres ruchomości w stawie kolanowym operowanym, wykazano, iż chorzy z Grupy Badanej osiągnęli istotny statystycznie $(p<0,0,5)$ korzystniejszy/ lepszy wyprost w obserwacji przeprowadzonej po 1. i 6. tygodniu od operacji rekonstrukcji ACL, w porównaniu z Grupą Kontrolną. recommended developing a complete and symmetric ROM through the realisation of the physiotherapy programme before and after the ACL reconstruction. They also concluded that particular attention should be paid to precise ROM examination and to achieving and maintaining full, symmetric ROM in the long term after the reconstruction [36].

In our study, while assessing ROM in the operated knee joint, it was revealed that compared to the control group, patients from the research group achieved a statistically significant $(\mathrm{p}<0.05)$ extension improvement 1 and 6 weeks after the ACL reconstruction.

Moreover, in the present study, pain intensity in the operated knee joint was assessed with the use of VAS. In the first measurements, i.e. 1 and 6 weeks after the surgery, a significant decrease $(p<0.05)$ in mean values of pain intensity in an operated knee was noted in both groups. During the last measurement, i.e. 12 weeks after the reconstruction, significantly lower pain intensity was noted in the research group than in the control group $(p<0.05)$. This is a significant observation since pain, as a basic clinical symptom and one of the major obstacles in the proper functioning of the musculoskeletal system, determines the direction of therapy and treatment outcomes. A similar opinion concerning pain intensity in a postsurgical period in patients after the ACL reconstruction was expressed by Yabroudi et al., who revealed high usefulness of controlling postsurgical pain and oedema in a knee join area [33]. While assessing the value of exercises in open and closed kinematic chains after the ACL reconstruction, Ucar et al. also applied the Visual Analogue Scale [37].

The results of our study and of other researchers dealing with an issue of complex treatment of patients after a complete ACL tear indicated the need for treating prehabilitation as one of the factors determining final treatment outcomes in this group of patients. In the observation, two values defining clinical symptoms significant for the course of rehabilitation (extension and pain intensity in the operated knee joint) appeared to be better in the research group. Physiological extension in a joint which was operated on was recovered faster in the group with physiotherapeutic preparation, which is confirmed by the results of the examination carried out 1 and 6 weeks after the surgery. The difference between the groups was statistically significant $(p<0.05)$. The delay of this process, and particularly the absence 
W badaniu własnym przeprowadzono również ocenę natężania bólu okolicy operowanego stawu kolanowego za pomocą wizualnej analogowej skali bólu VAS. W pierwszych punktach pomiarowych, po 1 i 6 tygodniach od zabiegu operacyjnego, w obu grupach prezentowanej pracy, uzyskano znamienne obniżenie średnich wartości natężenia bólu okolicy operowanego stawu kolanowego $(\mathrm{p}<0,05)$. W ostatnim, najbardziej odległym punkcie pomiarowym po 12 tygodniach po rekonstrukcji ACL, stwierdzono istotne statystycznie mniejsze natężenie bólu w Grupie Badanej w porównaniu z Grupą Kontrolną $(p<0,05)$. To ważna obserwacja, ponieważ ból jako podstawowy objaw kliniczny, jak również jedna $\mathrm{z}$ głównych przeszkód prawidłowego funkcjonowania narządu ruchu, wyznacza zakres działań terapeutycznych oraz decyduje o rodzaju wyniku leczenia końcowego. Podobną opinię o wartości pomiaru natężenia bólu w okresie pooperacyjnym u chorych po rekonstrukcji ACL wyrażają Yabroudi i wsp., którzy w swoim badaniu wykazali dużą przydatność kontrolowania po zabiegowego bólu i obrzęku okolicy stawu kolanowego [33]. Ucar i wsp., oceniając wartość ćwiczeń w otwartych i zamkniętych łańcuchach kinematycznych po rekonstrukcji ACL, również wykorzystywali wizualno-analogową skalę bólu VAS [37].

Wyniki pracy własnej oraz innych badaczy zajmujących się problematyką kompleksowego leczenia osób po całkowitym zerwaniu WKP wskazują na konieczność włączenia przedoperacyjnego przygotowania rehabilitacyjnego do grupy czynników decydujących o końcowym rezultacie leczenia $\mathrm{w}$ tej grupie chorych. W przeprowadzonej obserwacji dwie wartości określające istotne objawy kliniczne dla przebiegu leczenia usprawniającego (wyprost i natężenie bólu w operowanym stawie kolanowym) okazały się korzystniejsze w Grupie Badanej. Fizjologiczny wyprost w stawie, w którym dokonano rekonstrukcji ACL, przywracano szybciej $\mathrm{w}$ grupie $\mathrm{z}$ przygotowaniem fizjoterapeutycznym, co potwierdzają wyniki po 1 i 6 tygodniu od zabiegu. Zaobserwowana różnica pomiędzy grupami była statystycznie istotna $(p<0,05)$. Opóźnienie tego procesu, a zwłaszcza niepowodzenie $\mathrm{w}$ postaci braku uzyskania pełnego wyprostu, stanowi poważne zagrożenie dla przeszczepionego więzadła oraz samego stawu. Drugi objaw, którego wartości określone $\mathrm{w}$ prezentowanym badaniu potwierdzają istotną korzyść z prowadzonej rehabilitacji przedoperacyjnej, to natężenie odczuwanego bólu w okolicy of complete extension, constitutes a serious threat for the reconstructed ligament and the joint itself. The second symptom whose values determined in our study confirmed its significance for the prehabilitation is pain intensity in the area of an injured knee. In the last measurement, i.e. 12 weeks after the ACL reconstruction, significantly lower pain intensity was noted in the research group compared to the control group $(\mathrm{p}<0.05)$.

\section{Conclusions}

1. A quicker recovery of the range of extension in the operated knee joint and lower intensity of pain in the final measurement noted in the research group may indicate a certain therapeutic value of presurgical physiotherapy. 
urazowego stawu kolanowego. W ostatnim, najbardziej odległym punkcie pomiarowym, po 12 tygodniach od rekonstrukcji ACL, stwierdzono istotne statystycznie mniejsze natężenie bólu w Grupie Badanej w porównaniu $\mathrm{z}$ Grupą Kontrolną $(\mathrm{p}<0,05)$.

\section{Wnioski}

Obserwowany szybszy powrót zakresu ruchu wyprostnego $\mathrm{w}$ operowanym stawie kolanowym oraz mniejsze natężenie bólu w końcowym punkcie pomiarowym może wskazywać na pewną wartość terapeutyczną przedoperacyjnej fizjoterapii.

\section{Piśmiennictwo}

1. Beynnon BD. Risk Factors for Anterior Cruciate Ligament Injury: A Review of the Literature - Part1: Neuromuscular and Anatomic Risk. Orthopedic Surgery 2012; 1: 69-78.

2. Meuffels DE, Poldervaart MT, Diercks RL, Fievez AWFM, Patt TW, van der Hart, et. al. Guideline on anterior cruciate ligament injury. A multidisciplinary review by the Dutch Orthopaedic Association. Acta Orthop 2012; 83 (4): 379-86.

3. Chrzan D, Kusz D, Bołtuć W, Bryła A, Kusz B. Subiektywna ocena procesu rehabilitacji przez pacjentów po rekonstrukcji więzadła krzyżowego przedniego - doniesienie wstępne. Ortop Traumatol Rehabil 2013; 3(6): 215-25.

4. Stańczak K, Domżalski M, Synder M, Sibiński M. Powrót do aktywności fizycznej po rekonstrukcji więzadła krzyżowego przedniego - doniesienie wstępne. Ortop Traumatol Rehabil 2014; 5(6): 477-86.

5. Czamara A. Zastosowanie wyznaczników do oceny funkcjonalnej efektów rehabilitacji u pacjentów po rekonstrukcji więzadła krzyżowego przedniego. Ortop Traumatol Rehabil 2010; 6(6): 519-33.

6. Vaishya R, Agarwal AK, Ingole S, Vijay V. Current Trends in Anterior Cruciate Ligament Reconstruction: A Review. Cureus 2015; 7(11): e378.

7. Manske RC, Prohaska D, Lucas B. Recent advances following anterior cruciate ligament reconstruction: rehabilitation perspectives. Critical reviews in rehabilitation medicine. Curr Rev Musculoskelet Med 2012; 5:59-71.

8. Delince P, Ghafil D. Anterior cruciate ligament tears: conservative or surgical treatment? A critical review of the literature; Knee Surg Sports Traumatol Arthrosc 2012; 20:48-61.

9. Smith HC, Vacek P, Johnson RJ, Slauterbeck JR, Hashemi J, Shultz S, et al. Risk Factors for Anterior Cruciate Ligament Injury: A Review of the Literature — Part 1: Neuromuscular and Anatomic Risk Sport Health 2012; 4(1):69-78.

10. Vauhnik R, Morrissey MC, Rutherford OM, Turk Z, Pilih IA, Perme MP. Rate and Risk of Anterior Cruciate Ligament Injury Among Sportswomen in Slovenia. J Ath Train 2011; 46(1):92-8.

11. Alentorn-Geli E, Myer GD, Silvers HJ, Samitier G, Romero D, Lázaro-Haro C, et al. Prevention of non-contact anterior cruciate ligament injuries in soccer players. Part 1: Mechanisms of injury and underlying risk factors Knee Surg Sports Traumatol Arthrosc 2009; 17:705-29.

12. Alentorn-Geli E, Myer GD, Silvers HJ, Samitier G, Romero D, Lázaro-Haro C, et al. Prevention of non-contact anterior cruciate ligament injuries in soccer players. Part 2: A review of prevention programs aimed to modify risk factors and to reduce injury rates; Knee Surg Sports Traumatol Arthrosc 2009; 17:859-79.

13. Van Dyck P, Vanhoenacker MF, Gielen LJ, Dossche L, Van Gestel J, Wouters K et al. Three tesla magnetic resonance imaging of the anterior cruciate ligament of the knee: can we differentiate complete from partial tears? Skeletal Radiol 2011; 40:701-7.

14. Walde'n M, Martin Haogglund M, Magnusson H, Ekstrand J. Anterior cruciate ligament injury in elite football: a prospective three-cohort study. Knee Surg Sports Traumatol Arthrosc 2011; 19:11-19.

15. Bernardino S. ACL prosthesis: any promise for the future? Knee Surg Sports Traumatol Arthrosc 2010; 18:797-804.

16. Schindler SO. Surgery for anterior cruciate ligament deficiency: a historical perspective. Knee Surg Sports Traumatol Arthrosc 2012; 20:5-47.

17. Ryosuke Kuroda R, Matsushita T. Anatomic double-bundle anterior crucial ligament reconstruction with G-ST. Curr Rev Musculoskelet Med 2011; 4:57-64.

18. Miecznikowski M, Hagner W. Ocena skuteczności zabiegów fizjoterapeutycznych w usprawnianiu pacjentów po leczeniu operacyjnym uszkodzeń więzadła krzyżowego przedniego. Kwart Ortop 2013; 3:343-54. 
19. Boguszewski D, Tomaszewska I, Adamczyk JG, Białoszewski D. Ocena skuteczności Kinesiology Tapingu we wspomaganiu rehabilitacji pacjentów po rekonstrukcji więzadła krzyżowego przedniego. Doniesienie wstępne. Ortop Traumatol Rehabil 2013; 5(6): 469-78.

20. Wilk M, Trąbka R, Tomaszewski W. Wstępne wyniki zastosowania Protokołu Rehabilitacyjnego we wczesnym okresie u pacjentów po artroskopowej przezportalowej jedno i dwupęczkowej rekonstrukcji więzadła krzyżowego przedniego z użyciem ścięgien mięśni półścięgnistego i smukłego. Fizjoterapia Polska, 2009; 1(4): 97-103.

21. Czamara A. Wyznaczniki oceny funkcjonalnej sprawności narządu ruchu u pacjentów po rekonstrukcji więzadła krzyżowego przedniego stawu kolanowego. Fizjoterapia Polska, 2010; 4(4): 247-62.

22. Zduński S, Rongies W, Ziółkowski M, Kozieł T, Słomka B, Kazimierski P, et al. Ocena efektywności fizjoterapii przedoperacyjnej za pomocą skali Lysholma-Gillquista u pacjentów zakwalifikowanych do operacyjnej artroskopowej rekonstrukcji więzadła krzyżowego przedniego - badanie pilotażowe. Ortop Traumatol Rehabil 2015; 17(3):249-58.

23. Kubiak G, Fabiś J. Porównanie wyników oceny kolan po szyciu łękotek i rekonstrukcji więzadła krzyżowego przedniego w skalach Lysholma, HSS oraz IKDC. Ortop Traumatol Rehabil 2012; 77: 127-31.

24. Iriuchishima T, Horaguchi T, Morimoto Y, Negishi S, Kubomura T, Motojima S et al. Intensity of physiotherapy after anterior cruciate ligament reconstruction: a comparison of two rehabilitation regimen. Arch Orthop Trauma Surg 2010; 130:1053-8.

25. Van Grinsven S, Van Cingel REH, Holla CJM, Van Loon CJM. Evidence-based rehabilitation following anterior cruciate ligament reconstruction. Knee Surg Sports Traumatol Arthrosc 2010; 18:1128-144.

26. Månsson O, Kartus J, Sernert N. Pre-operative factors predicting good outcome in terms of health-related quality of life after ACL reconstruction. Scand J Med Sci Sports. 2013; 23(1):15-22.

27. Dunn WR, Spindler KP, Amendola A, Andrish JT, Kaeding CC, Marx RG et al. Which preoperative factors, including bone bruise, are associated with knee pain/symptoms at index anterior cruciate ligament reconstruction (ACLR)? A Multicenter Orthopaedic Outcomes Network (MOON) ACLR Cohort Study. Am J Sports Med. 2010; 38(9):1778-87.

28. Smith MA, Smith WT, Kosko P. Anterior cruciate ligament tears: reconstruction and rehabilitation. Orthop Nurs. 2014 JanFeb; 33(1):14-24.

29. Lawhorn KW, Howell SM, Traina SM, Gottlieb JE, Meade TD, Freedberg HI. The effect of graft tissue on anterior cruciate ligament outcomes: a multicenter, prospective, randomized controlled trial comparing autograft hamstrings with fresh-frozen anterior tibialis allograft. Arthroscopy. 2012; 28(8):1079-86.

30. De Valk EJ, Moen MH, Winters M, Bakker EW, Tamminga R, van der Hoeven H. Preoperative patient and injury factors of successful rehabilitation after anterior cruciate ligament reconstruction with single-bundle techniques. Arthroscopy. 2013; 29(11):1879-95.

31. Dragicevic-Cvjetkovic D, Jandric S, Bijeljac S, Palija S, Manojlovic S, Talic G. The effects of rehabilitation protocol on functional recovery after anterior cruciate ligament reconstruction. Med Arch. 2014; 68(5):350-2.

32. Grindem H, Granan LP, Risberg MA, Engebretsen L, Snyder-Mackler L, Eitzen I. How does a combined preoperative and postoperative rehabilitation programme influence the outcome of ACL reconstruction 2 years after surgery? A comparison between patients in the Delaware-Oslo ACL Cohort and the Norwegian National Knee Ligament Registry. Br J Sports Med. 2015; 49(6):385-9.

33. Yabroudi MA, Irrgang JJ. Rehabilitation and return to play after anatomic anterior cruciate ligament reconstruction. Clin Sports Med. 2013; 32(1):165-75.

34. Quelard B, Sonnery-Cottet B, Zayni R, Ogassawara R, Prost T, Chambat P. Preoperative factors correlating with prolonged range of motion deficit after anterior cruciate ligament reconstruction. Am J Sports Med. 2010; 38(10):2034-9.

35. Isberg J, Faxe'n E, Brandsson S, Eriksson BI, Ka“rrholm J, Karlsson J. Early active extension after anterior cruciate ligament reconstruction does not result in increased laxity of the knee. Knee Surg Sports Traumatol Arthrosc 2006; 14:1108-15.

36. Shelbourne KD, Freeman H, Gray T. Osteoarthritis after anterior cruciate ligament reconstruction: the importance of regaining and maintaining full range of motion. Sports Health. 2012; 4(1):79-85

37. Uçar M, Koca I, Eroglu M, Eroglu S, Sarp U, Arik HO, Yetisgin A. Evaluation of open and closed kinetic chain exercises in rehabilitation following anterior cruciate ligament reconstruction. J Phys Ther Sci. 2014; 26(12):1875-8

38. Shaarani SR, O'Hare C, Quinn A, et. al. Effect of prehabilitation on the outcome of anterior cruciate ligament reconstruction. Am J Sports Med. 2013; 41(9):2117-27.

39. Swank AM, Kachelman JB, Bibeau W, et. al. Prehabilitation before total knee arthroplasty increases strength and function in older adults with severe osteoarthritis. J Strength Cond Res 2011; 25(2):318-25.

40. Eitzen I, Håvard Moksnes H, Lynn Snyder-Mackler L, Risberg MA. A Progressive 5-Week Exercise Therapy Program Leads to Significant Improvement in Knee Function Early After Anterior Cruciate Ligament Injury. J Orthop Sports Phys Ther. 2010; 40(11): 705-721. 